\title{
14. THE CHEMISTRY OF INTERSTITIAL WATERS FROM THE UPPER OCEAN CRUST, SITE 395, DEEP SEA DRILLING PROJECT LEG 78B'
}

\author{
Russell E. McDuff, School of Oceanography, University of Washington ${ }^{2}$
}

\begin{abstract}
Chemical analysis of fluids sampled in situ during Leg 78B has been carried out. The fluids found in Hole 395A upon reoccupation of the site after a five-year hiatus were identical in composition to local bottom seawater to depths of at least $\mathbf{4 0 0}$ meters, suggesting drawdown. No local bottom-water component is present at 543 meters however. The chemistry of this deep sample shows a large depletion in magnesium, with charge balance maintained by sodium, rather than calcium, enrichment. Calcium is lost through calcite precipitation. A sediment interstitial-water sample from the offset Hole 395B has a chemical signature indicative of glacial influence, thereby constraining drawdown through the sediments to a velocity less than $0.5 \mathrm{~cm} / \mathrm{y}$.
\end{abstract}

\section{INTRODUCTION}

In the past several years much effort has been devoted to characterizing the chemical reactions which occur during seawater-ocean crust interaction. Two systems have been fairly well described: (1) those found in very young crust, involving convective transport of seawater and chemical exchange with fresh basalts at high temperature (Edmond et al., 1982, and references therein), and (2) those found in old crust when seawater supply through the sediment cover becomes diffusion-limited and chemical reactions in the upper basaltic layers proceed at low temperatures (McDuff, 1981; Lawrence and Gieskes, 1981, and references therein). In contrast, the transitional regime is poorly understood. The data that exist, principally from DSDP sampling, are not detailed enough to discern the origin of the small chemical anomalies found. Are they real or analytical artifacts? If real, do they result for instance from rapid flow of seawater through the sediments and upper basalts, coupled with slow rates of chemical reaction? Alternatively, does seawater flow through the upper basement alone, with discharge and recharge focused at basement outcrops and sediment pore-water chemistry dominated by diffusion, just as on older crust? A major unknown is the chemistry of the formation waters in the upper basement. With this in mind, we undertook analysis of fluids sampled during the reoccupation of Site 395 during Leg 78B.

\section{METHODS}

The analytical methods used in this study are summarized in Table 1. Sampling of fluids during Leg 78B took three forms:

1) When the ship arrived on site, the Barnes in situ sampler was progressively lowered into the existing Hole 395A to sample the fluids present at various horizons, with efforts made (described in the Operations section of the Site Summary, this volume) to minimize pumping and thus dilution with surface seawater.

\footnotetext{
1 Hyndman, R. D., Salisbury, M. H., et al., Init. Repts. DSDP, 78B; Washington (U.S. Govt, Printing Office). ton 98195.
}

Table 1. Methods used in Leg 78B interstitial water analyses.

\begin{tabular}{lll}
\hline Component & \multicolumn{1}{c}{ Method } & \multicolumn{1}{c}{ Reference } \\
\hline Alkalinity & Titration & Gieskes, 1974 \\
Chloride & Titration & Gieskes, 1974 \\
Calcium & Titration & Gieskes and Lawrence, 1976 \\
Magnesium & Titration & Gieskes and Lawrence, 1976 \\
Lithium & Atomic absorption & Gieskes and Johnson, 1981 \\
Potassium & Atomic absorption & Gieskes, 1974 \\
Strontium & Atomic absorption & Gieskes, 1974 \\
Manganese & Atomic absorption & Gieskes, 1974 \\
Silica & Colorimetric & Mann and Gieskes, 1975 \\
Nitrate & Colorimetric & \\
Sodium & Charge Balance & \\
\hline
\end{tabular}

Note: For sample PW5, a diluted IAPSO standard was used rather than the correction equations of Gieskes and Lawrence (1976).

2) As part of the sequence of packer experiments, a large-volume sample, consisting of a mixture of formation water and surface seawater introduced when flushing the hole for the televiewer run, was collected near the bottom of the hole by applying negative pressure to the formation. This was done by opening a sample chamber at atmospheric pressure in the volume of water below the packer after the packer had been inflated. The sample consists of three fractions isolated in the sampler chamber by check valves and each containing differing amounts of the end members.

3) The Barnes in situ sampler was used to obtain a single sample 70 meters into the sediment column at the offset Hole 395B.

Selected aliquots were analyzed aboard ship for $\mathrm{Cl}, \mathrm{Ca}$, and $\mathrm{Mg}$, following the standard protocol. It was apparent from these results that the fluids closely resembled seawater. In our laboratory, we first determined silica and nitrate concentrations, to identify samples consisting mainly of surface water introduced during drilling and those consisting chiefly of local deep water (Table 2). Complete analyses were then carried out on those samples which could be distinguished from these seawater sources (Table 3).

\section{EFFECTS OF TRANSPORT PROCESSES}

Hole 395A was originally drilled in late 1975 . It is not known what the exact composition of the fluid was when the hole was abandoned, but most likely it was dominated by local surface seawater introduced during drilling operations. Over the five years before reoccupation in March 1981, this fluid would have been modified by exchange with formation waters surrounding the hole 
and with local bottom seawater. It is useful first to summarize briefly the time scales for these processes.

Initially, strong chemical gradients would have existed between the water filling the hole and the adjacent formation waters. We can evaluate approximately the extent of diffusive exchange driven by these gradients. In the absence of further chemical reaction in the formation (see discussion following), and provided fluid flow is negligible and vertical gradients are small (relative to those at the rock/hole interface), we would have a radial diffusion problem involving a porous bed surrounding a circular, well-mixed reservoir. For our purposes, we will reduce this to the equivalent one-dimensional problem, as follows:

$$
\begin{array}{clll}
\frac{t=0}{c=c_{\text {formation }}} & \frac{t>0}{\frac{\partial c_{\text {formation }}}{\partial t}=D \frac{\partial^{2} c}{\partial x^{2}}} & \frac{\text { interval }}{x=\{0, l\}} \\
c=c_{\text {hole }} & \frac{\partial c_{\text {hole }}}{\partial t}=-\left.\frac{D}{r} \frac{\partial c_{\text {formation }}}{\partial x}\right|_{x=0} & x=\{-r, 0\}
\end{array}
$$

In this model $c$ is the concentration, $t$ is time, $D$ is the tortuosity and porosity-corrected diffusion coefficient $\left(D_{p} / F\right.$ of McDuff, 1981), and $x$ is the spatial coordinate. The well-stirred reservoir (representing the hole with radius $r$ ) lies to the negative side of the origin, and the porous bed (representing the formation with length $l$ ) lies to the positive side.

Following Crank (1970), the solution for $\Omega=D t / r^{2}$ $<1$ is

$c_{\text {hole }}=\left(c_{\text {formation }}-c_{\text {initial }}\right)(1-\exp \Omega \operatorname{erfc} \sqrt{\Omega})+c_{\text {initial }}$

where $c_{\text {initial }}$ is the initial concentration in the hole. For $D=1 \times 10^{-6} \mathrm{~cm}^{2} / \mathrm{s}$ in the formation (McDuff, 1978) and $r=15 \mathrm{~cm}$, the approximate radius of the hole, after 5 years,

$$
c_{\text {hole }} \cong 0.5\left(c_{\text {formation }}-c_{\text {initial }}\right)+c_{\text {initial }}
$$

Chemical reaction in the formation can modify this result through two effects: (1) higher gradients would be maintained than in the case of diffusion alone, thus accelerating the rate at which the water filling the hole would acquire a new chemical signature; (2) unless these reactions occur with the stoichiometry $\left(A_{\text {formation }}-\right.$ $\left.A_{\text {hole }}\right) /\left(B_{\text {formation }}-B_{\text {hole }}\right)$ for any two species A and B, the chemical changes observed will not accurately reflect the initial formation-water composition. It would be difficult to assess these effects in a quantitative way, although, as will be discussed later, it is likely that in the situation under discussion here their influence was small.

Circulation of fluids will modify this diffusion-only scenario once the horizontal velocity, $u$, exceeds the ratio $D / r$. This transition occurs with $u \sim 1-5 \mathrm{~cm} / \mathrm{y}$. for flow either into or out of the hole. If all horizontal flow across the wall of the hole is driven by vertical flow down the hole, then continuity of fluid requires that $\bar{u} A_{\text {wall }}=\bar{w} A_{\text {hole }}$, where $\bar{u}$ and $\bar{w}$ are the mean horizontal and vertical velocities, $A_{\text {wall }}$ is the wall area of the hole, and $A_{\text {hole }}$ is the cross-sectional area of the hole. Consequently, $\bar{w}<(2 h / r) \bar{u} \sim 5000 \bar{u}$, where $h$ is the present depth of the hole $(\sim 609 \mathrm{~m})$ and $r$ its radius. Using this result, two flow regimes can be distinguished. At the lowest velocities with advective (rather than diffusive) control, $\sim 1 \mathrm{~cm} / \mathrm{y}$., the vertical scale of transport may be small $(<250 \mathrm{~m}=50 \mathrm{~m} / \mathrm{y} . \times 5 \mathrm{y}$. $)$ relative to the depth of the hole. If horizontal flow is out of the formation, the chemical depth profiles will reflect formation waters at approximately the same depth; if horizontal flow is into the formation, bottom seawater will begin to penetrate, but not very far; that is, a clear indication of initial, or surface, seawater should still be found. At greater horizontal flows, the vertical scale of transport is much larger. Formation waters will be transported large distances vertically, or, conversely, bottom seawater will penetrate to great depth.

\section{ORIGIN OF FLUIDS}

Because of their distinctive chemistries, the silica and nitrate data (Table 2) can be used to infer the sources of the various fluids sampled. Surface seawater has very low silica concentrations $(\sim 0)$, local bottom seawater has intermediate values $(\sim 25 \mu \mathrm{mol} / \mathrm{kg})$ (Bainbridge 1981), and formation waters should have high values (several hundred $\mu \mathrm{mol} / \mathrm{kg}$ ). Nitrate concentration exhibits the same kind of surface-to-deep-water increase ( $\sim 0$ vs. $\sim 18 \mu \mathrm{mol} / \mathrm{kg}$ ), but would be expected to be no more than $18 \mu \mathrm{mol} / \mathrm{kg}$ in the formation waters and perhaps less, depending on the path that the fluid has followed

Table 2. Silica and nitrate concentrations in water samples from Site 395, Leg 78B.

\begin{tabular}{ccc}
\hline $\begin{array}{c}\text { Sub-bottom } \\
\text { depth } \\
(\mathrm{m})\end{array}$ & $\begin{array}{c}\mathrm{Si} \\
(\mu \mathrm{mol} / \mathrm{l})\end{array}$ & $\begin{array}{c}\mathrm{NO} \overline{3} \\
(\mu \mathrm{mol} / 1)\end{array}$ \\
\hline
\end{tabular}

Hole 395A: in situ samples

$\begin{array}{lrrr}\text { PW1 } & 105 & 27 & 18 \\ \text { PW3 } & 248 & 29 & 18 \\ \text { PW4 } & 400 & 25 & 17 \\ \text { PW5 } & 543 & 163 & <1 \\ & & (700) & \end{array}$

Hole 395A: packer samples

$\begin{array}{lrrr}\text { PK1A } & 582 & 24 & 1 \\ \text { PK1B } & 582 & 3 & <1 \\ \text { PK2 } & 582 & 3 & <1 \\ \text { PK3 } & 582 & 4 & <1\end{array}$

Hole 395B: in situ pore water sample

\begin{tabular}{llrr}
\multicolumn{1}{c}{ PW6 } & 70 & 241 & $<1$ \\
Local surface water & - & 0 & $<1$ \\
Local deep water & - & 25 & 18 \\
\hline
\end{tabular}

Note: Value in parentheses for PW5 is normalized to $\mathrm{Cl}=$ $545 \mathrm{mmol} / \mathrm{kg}$. We received two separate bottles of sample PK1. They clearly differ in composition, presumably because of heterogeneity in the packer chamber. In Hole 395A, the sediment/basalt contact is at $93 \mathrm{me}-$ ters sub-bottom. Hole 395B, offset 100 meters, was not drilled to basement. 
to reach the formation. Within this framework the following sources are indicated:

1) When we reoccupied the site, local bottom water was present to depths of at least 400 meters. This can be explained only by downwelling through the hole at velocities slightly greater than a hundred meters per year. Such velocities are lower than the minimum estimated from the thermal results $\left(2 \times 10^{5} \mathrm{~m} / \mathrm{y}\right.$. $)$, a consequence of the lower diffusivity of solutes relative to heat. In addition, it is worthwhile to note that there is no evidence of dilution with surface waters introduced during sampling operations; this demonstrates that sampling of this kind can be successfully carried out.

2) Because of its low nitrate concentration, the sample from 543 meters sub-bottom (PW5) can only represent some admixture of formation water and surface seawater. On this deployment the tool was lowered on the sandline without pumping; given this and the lack of dilution during sampling at shallower horizons, the likely source of any surface seawater is the 1975 drilling operation.

3) Only one packer sample contained detectable formation water, although it was greatly diluted with surface seawater.

\section{CHEMISTRY OF THE FORMATION WATER}

The sample from 543 meters sub-bottom (PW5) was diluted by the distilled water present initially in the sample capillary of the Barnes in situ sampler. The precise extent of dilution is unknown, but presumably the formation water has a chlorinity similar to seawater. Accordingly, all analyses were normalized to $\mathrm{Cl}=545$ $\mathrm{mmol} / \mathrm{kg}$ (Table 3 ). It should be noted, however, that for those elements exhibiting only small concentration anomalies, a different normalization will change the magnitude and even the sign of the inferred anomaly.

What does this normalized composition represent? Given the silica and nitrate data, the two possible transport regimes are very slow horizontal flow from the formation into the hole, or diffusive exchange between the formation and the hole. If these are the only processes

Table 3. Chemical data for water samples from Site 395, Leg 78B.

\begin{tabular}{lcccccc}
\hline & & & & & $\begin{array}{c}\text { Local } \\
\text { surface } \\
\text { water }\end{array}$ & $\begin{array}{c}\text { Local } \\
\text { deep } \\
\text { water }\end{array}$ \\
& \multicolumn{2}{c}{ PW5 } & PK1 & PW6 & & \\
Hole & $395 \mathrm{~A}$ & & $395 \mathrm{~A}$ & $395 \mathrm{~B}$ & - & - \\
$\begin{array}{l}\text { Sub-bottom } \\
\quad \text { depth (m) }\end{array}$ & 543 & & 582 & 70 & - & - \\
$\mathrm{Cl}$ & 127 & $(545)$ & 582 & 581 & 570 & 545 \\
$\mathrm{SO} 4$ & 4.1 & $(17.6)$ & 29.4 & 26.8 & 29.2 & 28.2 \\
$\mathrm{Alk}$. & 0.4 & $(1.7)$ & 2.6 & 2.4 & - & 2.4 \\
$\mathrm{Na}$ & 118 & $(506)$ & 498 & 496 & 485 & 467 \\
$\mathrm{~K}$ & 1.5 & $(6.4)$ & 10.8 & 7.1 & 10.7 & 10.2 \\
$\mathrm{Mg}$ & 5.12 & $(22.0)$ & 56.4 & 56.4 & 55.9 & 52.7 \\
$\mathrm{Ca}$ & 2.89 & $(12.4)$ & 10.8 & 10.8 & 10.6 & 10.3 \\
$\mathrm{Sr} \times 10^{3}$ & 23 & $(99)$ & 90 & 137 & 91 & - \\
$\mathrm{Mn} \times 10^{3}$ & 4.5 & $(19.3)$ & 1.1 & 26.2 & $<1$ & - \\
\hline & & & & & & \\
\hline
\end{tabular}

Note: All units mmol/kg. Values in parentheses for sample PW5 are normalized to $\mathrm{Cl}=545 \mathrm{mmol} / \mathrm{kg}$; see text. $-=$ not determined. operating, the conservative mixtures shown in Figure 1 are possible compositions for the formation water, with the larger anomalies more likely in the advective case and the smaller ones more likely in the diffusive case.

As discussed earlier, chemical reactions occurring after the introduction of surface seawater may alter this interpretation. Three considerations suggest that the effect is not large.

1) The formation water inferred to be present is not highly evolved, so the reaction of surface seawater with the rock should not be radically different.

2) At least in the case of sulfate, there is no plausible reaction to explain the observed depletion.

3) The kinetics of seawater-basalt reaction at low temperature are slow, with characteristic times of one year in systems having a ratio of exposed surface area $\left(\mathrm{cm}^{2}\right)$ per gram of rock per $\mathrm{ml}$ of solution of 50 , based on the data reported by Seyfried and Bischoff (1979). To achieve a similar reaction in the formation would require similar ratios. As a rough estimate, consider parallel cylindrical pores in a formation of porosity 0.2 (pore volume $=0.2 \mathrm{~cm}^{3}$, solid volume $\left.=0.8 \mathrm{~cm}^{3}\right)$. It follows that, with pores of radius $r \mathrm{~cm}$, the above ratio is 1.6 $\mathrm{cm}^{3} \mathrm{~g}^{-1} \mathrm{ml}^{-1} / r$. Thus, to achieve ratios as large as 50 requires the typical pore to be about $300 \mu \mathrm{m}$ in diameter. On the basis of the logging results, this is much smaller than the typical pore making up the porosity of the formation; the characteristic times of reaction are thus likely to be much greater than one year.

Chemically, the sample is not remarkable. Magnesium is significantly depleted and calcium slightly en-

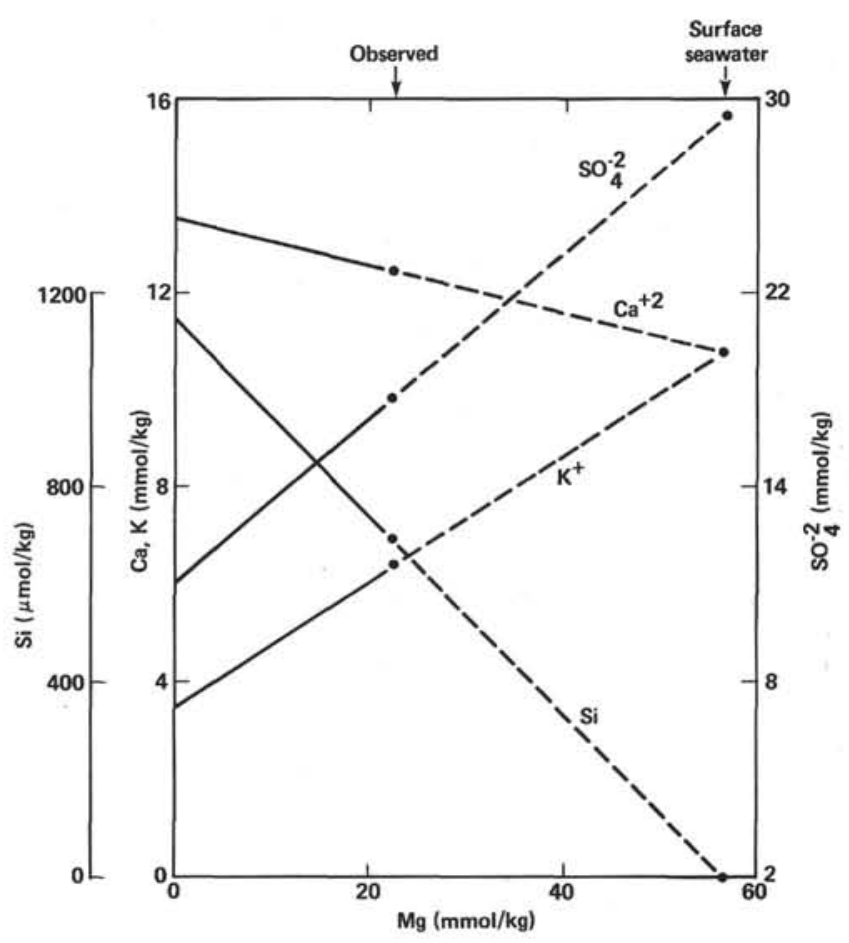

Figure 1. Possible compositions of formation water for the in situ sample from $543 \mathrm{~m}$ sub-bottom in Hole 395A, assuming no reaction effects (see text). Solid lines show the extrapolation using surface-seawater and observed compositions. 
riched, with $(\Delta \mathrm{Ca} / \Delta \mathrm{Mg})=0.07$. A value less than one is considered to be characteristic of a young low-temperature system; that is, calcium and sodium are free to accumulate in solution when magnesium remains available (McDuff, 1981). The $\Delta \mathrm{Na} / \Delta \mathrm{Ca}$ ratio is much higher than those observed in older systems, however. It is unlikely that this high ratio is the result of primary hydrolysis of basalt. Rather, the low $\Delta \mathrm{Ca}$ value is probably the consequence of calcite formation. Extensive vein fillings of calcite formed at low temperature have been documented at this site (Lawrence et al., 1979); such precipitation as this represents can occur only in systems with a continued supply of seawater carbonate. $\mathrm{Sr}$ is enriched slightly, but isotopic analysis has yet to be carried out. Sulfate is depleted and manganese enriched, probably indicating transit through sediments in which sulfate reduction was occurring at a modest rate. The manganese could also be of basaltic origin.

\section{COMPARISON WITH PREVIOUS RESULTS}

In the one prior study of basement formation waters, Mottl et al. (1983) reach a very different conclusion. They argue that reaction with surface seawater introduced during drilling is very rapid, with significant compositional changes occurring in several days. An analysis of their data reveals an outstanding problem, however.

As they mention, "It is even possible that the surface seawater has largely equilibrated with secondary minerals at the in situ temperature of $80^{\circ} \mathrm{C}$, although the lack of an ${ }^{18} \mathrm{O}$ shift limits the amount of rock with which the solution can have reacted." Indeed it does, and the problem can be treated quantitatively using the model described by Lawrence et al. (1976). From their isotopic balance equations,

$$
\delta_{\mathrm{d}}=\frac{x \delta_{\mathrm{a}}+(1-x) \delta_{\mathrm{b}}-1000 x(\alpha-1)}{x+(\alpha-1)+1}
$$

where $x$ is the mole fraction of oxygen in the solid phase before alteration, $(1-x)$ is the mole fraction of oxygen in the water before alteration, $\delta_{\mathrm{a}}$ and $\delta_{\mathrm{b}}$ are the respective isotopic compositions of the solid and fluid phases before alteration, $\delta_{\mathrm{d}}$ is the isotopic composition of the fluid phase after alteration, and $\alpha$ is the isotopic fractionation between the secondary mineral phase and the fluid. Parameters appropriate to the situation here are $\delta_{\mathrm{a}}$ $=6 \%, \delta_{\mathrm{b}}=0 \% 0$ and $\alpha=1.015$ (for the reaction basalt $\rightarrow$ montmorillonite at $100^{\circ} \mathrm{C}$; since the observed temperature was lower, this value is underestimated) (Lawrence et al., 1976). On the basis of the Mottl et al. (1983) data for the PS series of samples, $\delta_{\mathrm{d}}$ is on the order of $-0.1 \%$. Applying the above isotopic balance, it follows that $x$ must be less than 0.01 .

A typical silicate mineral contains $\sim 0.015 \mathrm{~mol} \mathrm{O}$ per gram of rock (e.g., $\mathrm{SiO}_{2}$ contains $0.53 \mathrm{~g} \mathrm{O}_{2}$ per gram of rock $=0.0166 \mathrm{~mol}$ per gram of rock) and water contains $0.056 \mathrm{~mol} \mathrm{O}$ per gram. Therefore, $x<0.01 \mathrm{im}$ plies that there is less than

$\frac{0.01 \mathrm{~mol} \mathrm{O} \text { in rock }}{0.99 \mathrm{~mol} \mathrm{O} \text { in water }} \times \frac{0.056 \mathrm{~mol} \mathrm{O}}{\mathrm{g} \text { water }} \times \frac{\mathrm{g} \text { rock }}{0.015 \mathrm{~mol} \mathrm{O}}=0.0377 \frac{\mathrm{g} \text { rock }}{\mathrm{g} \text { water }}$ or greater than $26 \mathrm{~g}$ water per gram of rock. This result can be put in context by recognizing that sample PS-1 is $\sim 1.5 \%$ enriched in $\mathrm{Cl}^{-}$relative to surface seawater, an enrichment which can only be explained, accepting the rapid-reaction hypothesis, by hydration of the rock; that is 0.015 gram of water has been lost per gram of water available. The product of these two numbers yields the minimum water content of the secondary mineral(s), $39 \mathrm{wt} . \%$. This is, of course, unreasonably high. A likely alternative is that the chemical signature seen by Mottl et al. (1983) is that of true basaltic basement waters, derived by reaction at higher temperatures and thus with smaller isotopic fractionation.

Indeed, this was their original interpretation (Mottl et al., 1980), before they obtained tritium analyses which they argue show no component of formation water. It is important to note, however, that of all their tritium results, surface seawater yields the lowest value, 2.46 TU. This is $8.5 \%$ below their highest value, 2.67 TU, and well outside their reported precision, $1.5 \%$. One can conclude that, during drilling operations, water with a tritium level of at least $2.67 \mathrm{TU}$ must have been introduced into the formation. Considering that the site (504) was in an equatorial upwelling region, and that most of the surface water expected at the sampling depth was thought to have been introduced four days earlier (Mottl et al., 1983), this is not unreasonable. Going one step further, a zero-tritium, zero-magnesium true basement-water composition would be consistent with surface tritium values of $\sim 3.0 \mathrm{TU}$. Verification would require a site-specific study of temporal tritium variations.

In sum, I believe that Mottl et al. did indeed sample true formation water, highly diluted. This would be a satisfactory explanation of their otherwise fortuitous finding that basal-sediment pore waters exhibit a chemical signature similar to their basement trend.

\section{CHEMISTRY OF THE SEDIMENT PORE WATER}

One sample of sediment pore fluid (PW6) was taken with the Barnes in situ sampler at a depth of 70 meters sub-bottom in Hole 395B. The corresponding measured temperature was low, corresponding to about $20 \%$ of the theoretical heat flow in crust of this age. Although one possible explanation was deep-water contamination during drilling operations, the nitrate level $(<1 \mu \mathrm{M})$ rules this out.

The other possibility is drawdown through the sediments. In major-ion chemistry the sample resembles seawater, with two important exceptions. First, sulfate is slightly depleted, consistent with nitrate depletion and manganese enrichment. Thus, drawdown is not rapid enough to erase the chemical signature of organic-carbon degradation in the sediment column. Second, chloride concentration is elevated $6.6 \%$ above deep-water values. At this chloride concentration, seawater magnesium concentration would be $56.2 \mathrm{mmol} / \mathrm{kg}$ and calcium concentration would be $11.0 \mathrm{mmol} / \mathrm{kg}$, both similar to the values observed. Evaporation prior to analysis can be ruled out, given the agreement with the values determined on shipboard. The most likely explanation is 
that this composition results from the general increase in seawater salinity during glacial advances during the past million years. For reference, the mean ocean salinity increases about $2.5 \%$ per 100 meters of ocean level decrease. In support, Lawrence et al. (1979) observed that sediment pore waters from Hole 395, drilled on Leg 45 , were enriched in $\delta^{18} \mathrm{O}$ (values of +0.4 to $+0.6 \%$ vs. SMOW) relative to present-day deep waters (with a value of $+0.1 \% 0$.) Such a signal can be introduced by either advection or diffusion. If advection is dominant, no elaboration is needed. In the case of diffusion, the mean signal of the last million years will have penetrated to a depth $x \sim \sqrt{D t} \sim 100$ meters, whereas present conditions (last 10,000 y.) will be felt only to a depth $x \sim$ 10 meters. (The details of a complete analysis are discussed in McDuff, unpublished data on Leg 86). The important constraint provided by this result is that the signal still exists. Drawdown must be at a rate of less than $70 \mathrm{~m} / 10,000 \mathrm{y}$, that is, less than about $0.5 \mathrm{~cm} / \mathrm{y}$.

\section{ACKNOWLEDGMENTS}

I thank Ms Elsa Peterson for assistance in the laboratory. The shipboard measurements were done by J. Denis. The work presented here benefited from the editorial reviews of Drs. Michael Mottl and Joris Gieskes. I especially appreciate access, prior to publication, to the Leg 69 results of Mottl et al., on which we differ considerably in interpretation. Ms Trudy Rasp prepared the manuscript. This chapter is University of Washington Contribution No. 1355.

\section{REFERENCES}

Bainbridge, A. E., 1981. GEOSECS Atlantic Expedition, Volume 2, Sections and Profiles: Washington (U.S. Govt. Printing Office).

Crank, J., 1970. The Mathematics of Diffusion (1st ed., revised): London (Oxford University Press).

Edmond, J. M., von Damm, K. L., McDuff, R. E., and Measures, C.I., 1982. The chemistry of the hot springs on the East Pacific Rise and their effluent dispersal. Nature, 267:187-191.

Gieskes, J. M., 1974. Interstitial water studies, Leg 25. In Simpson, E.S.W., Schlich, R., et al., Init. Repts. DSDP, 25: Washington (U.S. Govt. Printing Office), 361-394.
Gieskes, J. M., and Johnson, J., 1981. Interstitial water studies, Deep Sea Drilling Project, Leg 59. In Kroenke, L., Scott, R., et al., Init. Repts. DSDP, 59: Washington (U.S. Govt. Printing Office), 627-630.

Gieskes, J. M., and Lawrence, J. R., 1976. Interstitial water studies, Leg 35. In Hollister, C. D., Craddock, C., et al., Init. Repts. $D S D P$, 35: Washington (U.S. Govt. Printing Office), 407-424.

Lawrence, J. R., Drever, J. I., and Kastner, M., 1979. Low temperature alteration of basalts predominates at Site 395. In Melson, W. G., Rabinowitz, P. D., et al., Init. Repts. DSDP, 45: Washington (U.S. Govt. Printing Office), 609-612.

Lawrence, J. R., and Gieskes, J. M., 1981. Constraints on water transport and alteration in the oceanic crust from the isotopic composition of pore water. J. Geophys. Res., 86:7924-7934.

Lawrence, J. R., Gieskes, J. M., and Anderson, T. F., 1976. Oxygen isotope material balance calculations, Leg 35. In Hollister, C. D., Craddock, C., et al., Init. Repts. DSDP, 35: Washington (U.S. Govt. Printing Office), 507-512.

McDuff, R. E., 1978. Conservative behavior of calcium and magnesium in the interstitial waters of marine sediments: identification and interpretation [Ph.D. dissert.]. University of California, San Diego.

1981. Major cation gradients in DSDP interstitial waters: the role of diffusive exchange between seawater and upper oceanic crust. Geochim. Cosmochim. Acta, 45:1705-1713.

Mann, R., and Gieskes, J. M., 1975. Interstitial water studies, Leg 28. In Hayes, D. E., Frakes, L. A., et al., Init. Repts. DSDP, 28 : Washington (U.S. Govt. Printing Office), 805-814.

Mottl, M. J., Anderson, R. N., Jenkins, W. J., and Lawrence, J. R., 1983. Chemistry of waters sampled from basaltic basement in DSDP Holes 501, 504B, and 505B. In Cann, J. R., Langseth, M. G., Honnorez, J., Von Herzen, R. P., White, S. M., et al., Init. Repts. DSDP, 69: Washington (U.S. Govt. Printing Office), 475-484.

Mottl, M. J., Bender, M. L., Lawrence, J. R., Anderson, R. N., and Hart, S. R., 1980. Hot formation waters sampled from basement in the oceanic crust, IPOD Hole 504B. Am. Geophys. Union Trans., 61:995. (Abstract)

Seyfried, W. E., Jr., and Bischoff, J. L., 1979. Low temperature basalt alteration by seawater: an experimental study at $70^{\circ} \mathrm{C}$ and $150^{\circ} \mathrm{C}$. Geochim. Cosmochim. Acta, 43:1937-1947.

Date of Initial Receipt: February 7, 1983

Date of Acceptance: June 25, 1983 